\title{
The effect of recreational program on the level of psychological variables for obese children
}

\section{*Dr/ Amany Mohamed Al-Safty}

\section{The introduction and problem of research:}

One of the civilization indicators of nations and its prosperity is the extent to interest in breeding generations with its various categories, and this is reflected clearly in the extent to give it to the children the care, and attention. within the special sports recreational programs, and provide the inclusive growth possibilities in all aspects, which helps to prepare them for successful personal, social, and economic life in which each one has his own role in serving the community, whatever the size of his contribution.

The childhood is the crucial formative period of an individual's life, and what he learns, and keeps its impact on lifetime, so, the formative stage by which put the first seeds of personal features (16: 57) (17:240).

Tahani Abdul Salam (2001) suggests that the playing is a child's basic function, especially in the hours that he woke up, through the playing the child grows, and gaining many experiences, so the playing is the nature style to create opportunities to meet the needs of the child. (5: 101)

Playing is one of the most important fields, which will help to build the child's character, that's by what gives to him the opportunity to express himself, his abilities, and his creations, as it is a rich field with activities that satisfy the urgent need of the child to movement, meditation, reflection, and creativity, which acquired through practice of psychological, physiological, and skill fitness, Each of "Kemal Dervis, Mohammed Ahamahmy" (1997), and "Mohammed Ahamahmy, and Aida Abdul Aziz" (1998) indicate that the Playing provides the child experiences, information by spontaneous ways (12: 63), (18: 160) and "Tahani Abdul Salam "(2000) adds that the practice of playing, which

\footnotetext{
*Assistant professor - Department of Sports Recreation - Faculty of Physical Education - Tanta University, Egypt: 
helps to feel happiness, and pride of doing something (14: 245).

The anxiety has increased about the proportion of obesity for children in early childhood, until it became a global phenomenon according to the characterization of the World Health Organization, and this increase is not limited to the developing world, but also included many developing countries alike, and there are different and various reasons such as biological, psychological, social, economic and behind the problem of obesity. (33:256).

Franklin

indicates that the study of each of obesity, and physical activity for children in childhood, is one of the research priorities at the present time especially with the prevalence of obesity among children at all ages, the consequent of that is negative consequences on health. (21:120).

Obesity is one of the topics that affect many psychological, social, and economic aspects, so we can find interesting increasingly with the problem of obesity on the global level, but the diminishing interest at the local level, especially in the field of psychological science. (31:103) (35:107).

The research results that related with obesity indicate psychological and social consequences which are extremely bad and dangerous on this class, obese children are suffer severely from low psychological and social compatibility, so they are always subjected to severe psychological pressure as a result of criticism by others, resulting feeling ashamed, depressed, low self-concept that they have. (26:96).

From here, it has become necessary to give these children the skills of positive thinking, which help them to gain a positive personality capable of dealing with the future, as the positive thinking, earning the child selfconfidence, self-reliance, and many of the necessary qualities to deal with challenges of the future. (11:98).

Onsei Qassim (2009) mentions that the obese children, suffering from severe tendencies toward depression, low self-esteem, a sense of inadequacy, embarrassment, loss of self-confidence, as well 
as indifference and apathy, And the failure to respond appropriately to the emotional experiences, life situations, in addition to the emotional intensity of the emotional pressures, which they suffer from, as a result of obesity, and lack of acceptance of others to them, ridicule of them, and

they did not participate in many social activities. Which leads to withdrawal, Introversion, and avoid the group in addition to the disorder of the concept of body image that they have, compared to non-obese children. 3:21).

Huzzaa Mohamed

Huzzaa (2004) indicates that there is a high probability that the obese person in childhood stay fat in adulthood too, the possibility that the obesity in adulthood increases steadily, whenever the child became obese after the age of three, and that there is a correlation between obesity and the lack of physical activities for children. (15:65).

The proportion of obesity among children in Egypt, children from the age of $6: 10$ years $7 \%$ in 2001 , rose to $10 \%$ in 2006, and increased the prevalence of obesity to more than $25 \%$ rate in the preschool, children in the age stage of 11-14 years old were $14 \%$ male and $21 \%$ female. (80:25) (98:23).

The early childhood is an important period for the development of Kinetic skills of the child, and the positive development of kinetic behavior to him, during this phase, the kinetic development of child is closely related to all of his development of cognitive, emotional, and social development. (27:81) (30:21).

Through what has seen by the researcher the studies, such as study of Christine Won Chung (2013) (18) entitled "The efficiency of the life of pre-school obese children, and those who overweight in China,and the study of Alaa Mohamed Rabie (2012) (9), entitled "Effect of proposed exercise program on body composition, the obese pupils from 9-11 years old in El Menia, And Fatema El Zahraa Magdi's study (2011) (10) entitled "the body image for obese child, the slim child, and its relationship with social interaction, Margarita's study, et al. (2011) (28) entitled "the physical activity, playing, and 
its relationship of obesity to pre-school children, And Mohammed bin Majid Ahmed's study (2009) (13) entitled "the fitness cardiorespiratory study, for obese children and adolescents, McGrady's study, (2009) (29) entitled" The correlation between participation in the kindergarten, and obesity for pre-school children, And Erin's study, et al. (2008) (20) entitled "The correlation between the child care program, and obesity for preschool children, and that references to the importance of using recreational and sports programs for obese children. The researcher believes that the recreational psychological sports activities are considered fertile field the individual gets from it the psychological, and social values, so providing these appropriate recreational sports programs, particularly for children. Is the duty of society towards children, as those programs success depends on the understanding of the officials largely to the nature of obese children requirements, that is the importance of current research in a scientific attempt to identify "the effect of recreational program at the level of some psychological variables for obese children".

\section{The research aim}

The research aims to identify "the effect of recreational program at the level of some psychological variables for obese children.

\section{Research hypotheses}

- $\quad$ There are statistically significant differences between the averages of pre-and postmeasurements at the level of anxiety of the obese children.

- There are statistically significant differences between the averages of pre-and postmeasurements at the level of psychological compatibility of the obese children.

\section{Some of the terms contained in the research: Obese Child:}

Is a child who has a body mass index, (30) or more, which is located between percentile average $90 \%$ to $95 \%$, using the appropriate tables for the child's age, and sex which refers to the increased amount of the fat in the body. (34:52) (32:85).

\section{Recreation games:}

Recreation games are simple organized games with 
the participation of more than one child, to compete, according to simple rules, predominantly the recreational, and entertainment, it has been using tools, or devices, or without any of it. (Operational definition)

\section{The anxiety:}

Is an unpleasant emotional experience suffered by the individual when he feels fear, or threat of something, without being able to identify it clearly. (9:54).

The psychological

\section{adjustment:}

Is the individual's ability to comply with himself, others, that satisfies himself, to accept himself as accepting of others, that he has the ability to acquire the skills to deal with those who around him, and the formation of positive relationships. (24:11).

\section{The research method}

The researcher has used the experimental method, whereas the method is appropriate to the nature of this research using the experimental design for one group, so as to achieve the objectives, and research hypotheses.

The research sample and community

The research community includes, for obese children, El Gharbia Governorate, and those who are regularly attended in the unity of the gym, and slimming at Tanta Sports club. The community size has reached (45) forty-five boys and girls ranging in age from 9 to 12 years, the researcher has chosen a random sample, (through observation the researcher), and measuring the strength of the body weight (30) children "of the study community, as well as (15) children to conduct the exploratory study. 
Table (1)

The arithmetic average, the intermediary, the standard deviation, torsion coefficient of the timing age, and psychological variables., under discussion for obese children $(N=45)$

\begin{tabular}{|c|c|c|c|c|c|c|}
\hline \multicolumn{3}{|c|}{ Parameters } & Average & Mediator & $\begin{array}{l}\text { Standard } \\
\text { deviation }\end{array}$ & $\begin{array}{c}\text { Torsion } \\
\text { modulus }\end{array}$ \\
\hline \multicolumn{3}{|c|}{ Weight } & 64.52 & 64.00 & 1.58 & 0.987 \\
\hline \multicolumn{3}{|c|}{ Chronological age } & 10.47 & 10.40 & 0.62 & 0.012 \\
\hline \multicolumn{3}{|c|}{ Anxiety scale } & 138.21 & 135.00 & 3.84 & 2.50 \\
\hline \multirow{15}{*}{ 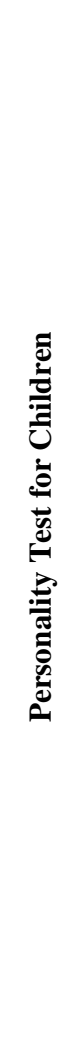 } & \multirow{7}{*}{ 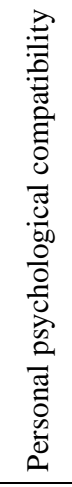 } & Child's self-reliance & 4.28 & 4.25 & 0.21 & 0.020 \\
\hline & & Child's self-worth sense & 4.28 & 4.25 & 0.14 & 0.642 \\
\hline & & Child's sense of freedom & 4.51 & 4.50 & 0.32 & 0.0097 \\
\hline & & Child's sense of belonging & 4.18 & 4.15 & 0.12 & 0.750 \\
\hline & & $\begin{array}{l}\text { To be free from the tendency } \\
\text { to individually }\end{array}$ & 4.26 & 4.25 & 0.014 & 0.510 \\
\hline & & $\begin{array}{l}\text { To be free from neurotic } \\
\text { symptoms }\end{array}$ & 4.81 & 4.80 & 0.032 & 0.937 \\
\hline & & Total degree & 26.32 & 26.20 & 0.115 & 1.088 \\
\hline & \multirow{7}{*}{ 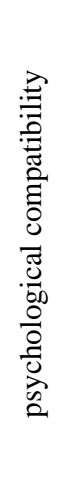 } & Social levels & 5.38 & 5.35 & 0.32 & 0.281 \\
\hline & & Social skills & 5.61 & 5.60 & 0.21 & 0.093 \\
\hline & & $\begin{array}{l}\text { To be free from anti- } \\
\text { community inclinations }\end{array}$ & 5.28 & 5.25 & 0.014 & 0.789 \\
\hline & & Family's relationships & 5.41 & 5.40 & 0.021 & 0.226 \\
\hline & & School's relationships & 4.84 & 4.80 & 0.025 & 0.960 \\
\hline & & $\begin{array}{ll}\text { Local } & \text { environment's } \\
\text { relationships } & \\
\end{array}$ & 5.18 & 5.15 & 0.32 & 0.281 \\
\hline & & Total degree & 31.70 & 31.55 & 0.11 & 1.859 \\
\hline & \multicolumn{2}{|c|}{ Total degree for the test } & 58.02 & 57.75 & 1.25 & 0.648 \\
\hline \multicolumn{3}{|c|}{$\begin{array}{l}\text { Table (1) shows that the } \\
\text { torsion coefficients values to } \\
\text { the variables: age, weight, } \\
\text { anxiety, } \\
\text { compatibility with both } \\
\text { personal and social, research }\end{array}$} & \multicolumn{4}{|c|}{$\begin{array}{l}\text { sample has ranged between } \\
0.012: 2.50) \text { that is confined } \\
\text { between }( \pm 3) \text { which indicates } \\
\text { equinoctial sample distribution } \\
\text { in those variables. }\end{array}$} \\
\hline
\end{tabular}




\section{Data collection tools}

To collect the data for the research, the researcher has used following tools:

First, the psychological measures:

1- Anxiety scale prepared by/ Adel Al ashwal, and Abdul-Aziz Al Shakhs

2- Personality Test prepared by/ Hana Attia (1983) Secondly, recreational sports program prepared by / the researcher

\section{Third: The basic study:}

In the light of the knowledge of the kinetic properties of the sample, and in the light of determining the overall objective of the program, the researcher has developed the following steps, Implementation of the basic experience of the research, and the application of the proposed recreational program through:

\section{The pre-measurement:}

The researcher has conducted the premeasurement in psychological tests for the obese children who participants in the study of the research group, through the measures which have used, and in the period from $08 / 01 / 2015$ to $08 / 08 / 2015$.

\section{Implementation of the basic experiment:}

The researcher has used experimental variable, (recreational program) on the research group, in the period from 08.10.2015 to 15.10.2015 for a period of 10 weeks, the rate of (3) units per week, the total (30) unit, the time of unity (60) minutes.

- The objective of the program:

The program aims to identify, effect of recreational program at the level of some of the Psychological variables for obese children.

\section{The program time:}

The proposed program for the application of recreational programs, for a period of two and half months (10) weeks, by 3 units a week (Sunday Tuesday - Thursday) for a total of (30) classes, the class time (60 minutes), were distributed to the time of each class (60) minutes, on its parts (10 min) primer activity, (45 min) basic activity (recreational games), (5 min) final activity. 
Table (2)

Timetable distribution unit

\begin{tabular}{l|c}
\hline \hline \multicolumn{1}{c|}{ Unit parts } & Time \\
\hline \hline Primer activity & $10 \mathrm{~min}$ \\
\hline $\begin{array}{l}\text { Basic activity } \\
\begin{array}{l}\text { Recreational games, competitions and physical } \\
\text { exercises using various games }\end{array}\end{array}$ & $45 \mathrm{~min}$ \\
\hline Final activity & $5 \mathrm{~min}$ \\
\hline \hline
\end{tabular}

The parts of the program:

A- Primer activity, its duration 10 minutes:

It aims to prepare the child psychologically, physically, stimulate blood circulation, and promote enthusiasm for the active positive participation in the program units, and preparation to participate in a recreational activity, it is a set of simple exercises.

B- Basic activity, its duration 45-minutes:

It is a collection of recreational sports games, simple competitions, and educational activity, which are fun, pleasure, and cooperation, and in order to develop the psychological qualities for obese children of research sample.

C- The final activity: its duration 5 minutes:

It aims to relieve the body to return to a natural status, includes a group of relaxation exercises.

\section{The post measurement:}

The researcher has conducted the post measurement to the psychological qualities tests for children who are participants in the study under discussion, in the period from $16 / 10 / 2015$ to 23/10/2015.

Forth: The statistical treatments that used:

The researcher has used the following statistical treatments:

The arithmetic average standard deviation - the mediator - torsion coefficient, the correlation coefficient- $(\mathrm{T})$ test.

Presentation and discussion of results

First: The results: - 
Table (3)

Significance of differences between the pre-and postmeasurements in the level of anxiety for the sample under discussion $(\mathbf{N}=\mathbf{3 0})$

\begin{tabular}{|c|c|c|c|c|c|c|c|c|c|}
\hline \multirow{2}{*}{ Parameter } & \multirow{2}{*}{$\begin{array}{l}\text { Measuring } \\
\text { Unit }\end{array}$} & \multicolumn{2}{|c|}{$\begin{array}{l}\text { Pre- } \\
\text { measurement }\end{array}$} & \multicolumn{2}{|c|}{$\begin{array}{l}\text { Post } \\
\text { measurement }\end{array}$} & \multirow{2}{*}{$\begin{array}{l}\text { The } \\
\text { difference } \\
\text { between } \\
\text { two } \\
\text { averages }\end{array}$} & \multirow{2}{*}{$\begin{array}{l}\text { The } \\
\text { improvement } \\
\text { percentage }\end{array}$} & \multirow{2}{*}{$\begin{array}{l}\mathrm{T} \\
\text { Value }\end{array}$} & \multirow{2}{*}{$\begin{array}{l}\text { Significance } \\
\text { level }\end{array}$} \\
\hline & & a.v & s.t & a.v & s.t & & & & \\
\hline $\begin{array}{l}\text { Anxiety } \\
\text { scale for }\end{array}$ & degree & 138.21 & 3.84 & 121.58 & 2.58 & 16.63 & $13.67 \%$ & 3.88 & Signify \\
\hline
\end{tabular}

The value of Tabulated (T) at the significance level $(0.05)=1.708$

Table (3) shows that there are significant differences between the averages of preand post measurements at the level of anxiety scale for the

\section{Table (4) \\ Significance of differences between the post and pre- measurements, in the level of psychological compatibility for the \\ sample under discussion $(\mathrm{N}=30)$}

\begin{tabular}{|c|c|c|c|c|c|c|c|c|c|c|c|}
\hline \multirow{2}{*}{\multicolumn{3}{|c|}{ Parameter }} & \multirow{2}{*}{ 羿 } & \multicolumn{2}{|c|}{$\begin{array}{c}\text { Pre- } \\
\text { measurement }\end{array}$} & \multicolumn{2}{|c|}{$\begin{array}{c}\text { Post } \\
\text { measurement }\end{array}$} & \multirow{2}{*}{$\begin{array}{c}\text { The } \\
\text { difference } \\
\text { between } \\
\text { two } \\
\text { averages }\end{array}$} & \multirow{2}{*}{ 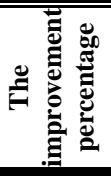 } & \multirow{2}{*}{$\begin{array}{c}\text { T } \\
\text { Value }\end{array}$} & \multirow{2}{*}{ 总 } \\
\hline & & & & a.v & s.t & a.v & s.t & & & & \\
\hline \multirow{10}{*}{ 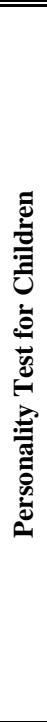 } & \multirow{7}{*}{ 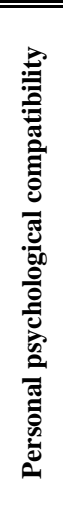 } & $\begin{array}{ll}\begin{array}{l}\text { Child's } \\
\text { reliance }\end{array} & \text { self- } \\
\end{array}$ & Degree & 4.28 & 0.21 & 6.18 & 0.14 & 1.90 & $44.39 \%$ & 3.58 & signify \\
\hline & & $\begin{array}{l}\text { Child's self- } \\
\text { worth sense }\end{array}$ & Degree & 4.28 & 0.14 & 6.22 & 0.15 & 1.94 & $31.18 \%$ & 3.15 & signify \\
\hline & & $\begin{array}{l}\text { Child's sense } \\
\text { of freedom }\end{array}$ & Degree & 4.51 & 0.32 & 6.24 & 0.32 & 1.73 & $38.35 \%$ & 3.62 & signify \\
\hline & & $\begin{array}{l}\text { Child's sense } \\
\text { of belonging }\end{array}$ & Degree & 4.18 & 0.12 & 6.37 & 0.25 & 2.19 & $52.39 \%$ & 3.15 & signify \\
\hline & & $\begin{array}{l}\text { To be free } \\
\text { from } r \text { the } \\
\text { tendency to } \\
\text { individually }\end{array}$ & Degree & 4.26 & 0.014 & 6.45 & 0.14 & 2.19 & $51.40 \%$ & 3.84 & signify \\
\hline & & $\begin{array}{l}\text { To be free } \\
\text { from neurotic } \\
\text { symptoms }\end{array}$ & Degree & 4.81 & 0.032 & 6.21 & 0.36 & 1.40 & $29.10 \%$ & 3.45 & signify \\
\hline & & Total degree & Degree & 26.32 & 0.115 & 37.67 & 0.14 & 11.35 & $43.12 \%$ & 3.69 & signify \\
\hline & \multirow{3}{*}{ 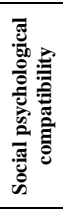 } & Social levels & Degree & 5.38 & 0.32 & 6.88 & 0.21 & 1.50 & $27.88 \%$ & 3.51 & signify \\
\hline & & Social skills & Degree & 5.61 & 0.21 & 6.87 & 034 & 1.62 & $22.45 \%$ & 3.26 & signify \\
\hline & & $\begin{array}{l}\text { To be free } \\
\text { from anti- } \\
\text { community } \\
\text { inclinations }\end{array}$ & Degree & 5.28 & 0.014 & 7.15 & 0.52 & 1.87 & $35.41 \%$ & 3.87 & signify \\
\hline
\end{tabular}

research sample, whereas the value of calculated $(\mathrm{T})=(3.88)$ by improvement $(13.67 \%)$ in favor of the post measurement. 
Follow Table (4)

Significance of differences between the post and premeasurements, in the level of psychological compatibility for the sample under discussion $(\mathrm{N}=30)$

\begin{tabular}{|c|c|c|c|c|c|c|c|c|c|}
\hline \multirow{2}{*}{ Parameter } & \multirow{2}{*}{ 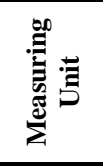 } & \multicolumn{2}{|c|}{$\begin{array}{c}\text { Pre- } \\
\text { measurement }\end{array}$} & \multicolumn{2}{|c|}{$\begin{array}{c}\text { Post } \\
\text { measurement }\end{array}$} & \multirow{2}{*}{$\begin{array}{c}\text { The } \\
\text { difference } \\
\text { between } \\
\text { two } \\
\text { averages }\end{array}$} & \multirow{2}{*}{ 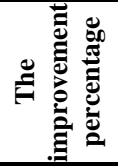 } & \multirow{2}{*}{$\begin{array}{c}\text { T } \\
\text { Value }\end{array}$} & \multirow{2}{*}{ 递 } \\
\hline & & a.v & s.t & a.v & s.t & & & & \\
\hline $\begin{array}{l}\text { Family's } \\
\text { relationships }\end{array}$ & Degree & 5.41 & 0.021 & 7.32 & 0.36 & 1.91 & $35.30 \%$ & 3.21 & signify \\
\hline $\begin{array}{l}\text { School's } \\
\text { relationships }\end{array}$ & Degree & 4.84 & 0.025 & 7.26 & 0.041 & 2.42 & $50.00 \%$ & 3.10 & signify \\
\hline $\begin{array}{l}\text { Local } \\
\text { environment's } \\
\text { relationships }\end{array}$ & Degree & 5.18 & 0.32 & 7.18 & 0.27 & 2.00 & $38.61 \%$ & 3.69 & signify \\
\hline Total degree & Degree & 31.70 & 0.11 & 42.57 & 0.14 & 10.87 & $34.29 \%$ & 4.18 & signify \\
\hline $\begin{array}{l}\text { Total degree for the } \\
\text { test }\end{array}$ & Degree & 58.02 & 1.25 & 80.24 & 0.26 & 22.22 & $38.29 \%$ & 3.21 & signify \\
\hline
\end{tabular}

The value of Tabulated $(T)$ at the significance level $(0.05)=1.708$

Table (4) shows that there are statistically significant differences between the averages of pre-and postmeasurements at the level of psychological compatibility scale for the research sample, whereas came from the value of calculated (T) (3.10 to 4.18), its larger than its Tabulated value at the significant level (0.05), which shows an improvement in favor of post measurement.

Second: The discussion of the results: -

From the research results, it is clear that the table (3) shows that there are statistically significant differences between the average two measurements pre and post measurements to the research sample in the level of anxiety, in the direction of the post measurement, and the researcher attributes that to the conclusion of the proposed recreational program, And what covered it by different activities, has contributed positively to alleviate anxiety, the sample under discussion therefore, the results showed the existence of differences in the degree of anxiety, before the application of the program, after the application, and in the direction of the post measurement, the researcher believes that, the improvement is due to the recreational sports program, which included different exercises games, 
which contributed positively, in the sense of a state of reassurance and reduce the level of anxiety, Where these exercises helps, in reducing the heartbeat rate and get rid of stress, reduce the effect of physiological changes in the body, which in turn lead to disability feeling, tension, anxiety.

As for the discussions, kinetic games have positive role in modifying the child's useless ideas into useful ideas, for example, I'm going to run with my colleagues, I am going to win, and I can abstain from eating candy. As it was to play the roles that the program included an important role in a child learn to think more positively, through its representation of the role of a child, that can fulfill all the works, through the magic saying "I can do so (6:41). (22:69)

And this is consistent with what indicated by, all of the Amir al-Qurashi (2001) (2), Abdul Hamid Sharaf (2005) (8) it is necessary to focus on the diverse learning environment, which takes into account the concerns, and positives, and the needs of children, And the use of different materials, through various activities, to provoke the child and attract his attention, participation, and diversity strategies, and techniques that used in the activities, and positive dialogue with the self, observation, intermittent reinforcement, and rewards (material - moral) In kinetic activity, and repetition in the music activity, imitation, simulation, role playing, discussions, correct misconceptions, and homework in narrative activity, to develop, improve selfconfidence.

Thereby first hypothesis has been achieved, which provides that there are statistically significant differences between the averages of pre-and postmeasurements at the level of anxiety for obese children.

Results of the research indicate that table (11) shows that There are statistical significant differences between the two measurements average pre, and post to the research sample, in the level of psychological compatibility, with its dimensions, personal, social, and in the direction of the post measurement, The researcher attributes that result to be that, the proposed recreational program, which 
involves several activities, contributed to the creation of many opportunities to improve personal and social adaptation, through the exercise of a sense of success, and to cooperate with his colleagues and competition them.

The proposed recreational program which involves a variety of activities, whether sports, or indicative contributed positively to the achievement of personal adaptation and helped him in self-reliance, where that participation in sports competitions, develops a child's self-reliance and a sense of self-worth, , Feeling the child belonging to the group, to which he belongs within the playing group, and try to make the effort to win, and his team, and that makes obese child is liberated from himself, selfishness, but focus all his attention on winning, for his group , against the other group, therefore it makes the child feels good about himself, but also accepts the society, and be more positive to the society that around him.

On the other hand, research results have made it clear that there is increasing in the social skills for the obese children through the participation in playing groups of the sports which included in this program, as well as the small games, which contributed positively in the development of the spirit of cooperation, participation and the happiness of others, and that the recreational sports proposed program has a positive impact on strengthening social relations between the obese child, and the society in which around him, such as family, school, and relationships with the environment around him, which also has been reflected on the improvement of his psychological adaptation.

This is consistent with what referred to by both Saeed Hosni Alezza (2002) and Alaa Mohamed Rabie (2012 ) (9) of obesity affects the children's kinetic activity practicing which is an important element of the enhanced elements of the child's health and his growth in early childhood, that the kinetic activities provide a valuable opportunity for the child to be able to express himself, explore his capabilities and even defiant them too, and provide the friction with others and interacting with them, also the 
experiments and kinetic experiences which undergone by the child at this stage lead to help him to feel his achievement and enjoy the participation and selfconfidence.

The researcher believes that the problem of obesity and the size of the problems that it caused, whether healthy problems represented in the incidence of heart diseases and vascular and cerebral arteriosclerosis and the close relationship between obesity and some cancers (kidney colon - breast), as well as psychological and social problems that is no less dangerous for the health aspect that the scientists and researchers focus on it.

This is consistent with what referred by David Davies p (2005) (19) the overweight and the obesity of the child can lead to make the child less active and more inclined to physical inactivity, particularly as the process of doing physical activity is stressful for the obese child where it requires that the obese child carry a heavy body in order to do this activity.

Also the discussion method helped to lighten the child's mind and raising some of his queries, which are mostly closer to his realism problems, and to clarify the program's activities for children so they are not opaque to not feel bored while doing it, and the sequence and arrangement of the ideas and paragraphs of the program's activities in a logical way help the children practicing of these activities without feeling bored, either fiction activity makes the child's mind goes in a fantasy world full of animals and birds, which are easy for the child to merge with and exhibit their behavior, and this is represented the general objectives of the stories that were used in the current program, which helps to gain a psychological compatibility.

Thereby the second hypothesis has been achieved, which provides that there are statistically significant differences between the averages of pre and post measurements at the level of psychological compatibility of the obese children.

\section{Conclusions}

1. The proposed recreational program has a positive effect on the 
psychological anxiety of the obese children.

2. The proposed recreational program has a positive effect on the psychological compatibility of the obese children.

\section{Recommendations}

3. The need to provide appropriate recreational programs for the obese children to help in achieving of the right mental health to that category.

4. The attention of the officials to provide all the necessary resources as the courts and sporting equipment for practicing the sports activities for the obese children.

5. Working on the provision of appropriate opportunities to achieve the succeed experience for obese children, which makes them earn the self-confident and the compatibility with the community.

\section{References}

\section{Ahmed Mohammed}

Sawalha (2004): "The psychology of play", Dar Arab Thought, 2nd copy, Cairo.

\section{Amir Ibrahim Qurashi} (2001): "Curriculum and dramatic entrance", the world of books for publication, Cairo.

\section{Onsei}

Mohamed

Ahmed Kassem (2009): "Selfconcept among kindergarten obese children", childhood Journal, the Faculty of kindergarten, Cairo University, May .221 to 274.

4. Bader Mohammad AlAnsari (2006):" Reference of personality disorders", Dar Alketab alhadith, Cairo.

\section{Tahany Abdul Salam:}

"Recreation and the, recreational education", Dar Arab Thought, Cairo, 2001.

\section{Khalid Abdul Raziq} Alsayed (2002): "The psychological construction of the obese child", ( a dynamic study), the second scientific conference, (the child the best investment for the future of the Arab world), Cairo University, Faculty of Kindergarten P.598 to 622 , Cairo.

7. Said Hosni Alezza (2002): "Special education for children with behavioral disorders", the house of scientific publication and distribution, Jordan.

8. Abdul Hamid Sharaf (2005 m):" Kinetic education of children without disabilities and disability Challenger", 2nd copy, Cairo.

9. Alaa Mohamed Rabie (2012), "the impact of a 
proposed sports program on the body composition of obese students from 9-11 years at Minia", PhD Thesis, Faculty of Physical Education, Minia University.

10. Fatma-alzahraa Magdi (2011):"The body image for the obese child and the thin child and its relationship with the social interaction", Master thesis, kindergarten Faculty, Cairo University.

\section{Fahim Mustafa}

Mohammed (2005): "The child and thinking skills in kindergarten and elementary school," Cairo, Dar Arab Thought.

\section{Kamal Darwish,}

Mohammed Alhamahmy:

"Modern vision for recreation and leisure", book publishing center, Cairo 1997.

13. Mohammed Bin Majid Ahmed (2009): "The study of cardiorespiratory fitness of the obese children and adolescents", PhD Thesis, Faculty of Physical Education, University of Alexandria.

\section{Mohammed}

Alhamahmy, Aida Abdul Aziz: "Recreation between theory and practice", 2nd copy, book publishing center, Cairo, 1998.

\section{Hozzaha Mohammed} Hozzaha (2004): "Obesity and physical activity in early childhood how their deployment, and what is the relationship between them?", Nutrition of children in the Arab Gulf states, Bahrain Centre for Research and Studies Manama, Bahrain.

16. Huda

Alnashef: "Design of educational programs for pre-school children", Dar Alkettab alhadetha, Cairo, 2003. 